Medievalia 23/I (2020), 9-I4 - ISSN: 20I4-84Io (digital)

DOI: https://doi.org/10.5565/rev/medievalia.518

\title{
TABERNACLE-ALTARPIECES: VARIETY WITHIN UNITY
}

\author{
LOS RETABLOS-TABERNÁCULO: \\ VARIEDAD DENTRO DE LA UNIDAD
}

Fernando Gutiérrez Baños

Universidad de Valladolid

fbanos@fyl.uva.es

https://orcid.org/00oo-0002-5352-2027

Justin Kroesen

Universitetsmuseet $i$ Bergen

Justin.Kroesen@uib.no

https://orcid.org/oooo-0002-4I4I-422I

Elisabeth Andersen

Norsk institutt for kulturminneforskning elisabeth.andersen@niku.no

https://orcid.org/o000-0002-0358-6145

Altarpieces are among the most outstanding and celebrated achievements of medieval art. They were the fruits of the joint efforts, skills and ambitions of artists and patrons. Often combining different media, they reflected a great deal of the faith, ideals, hopes, anxieties and devotions of Christian communities. Altarpieces were erected in churches of all ranks, from cathedrals and monumental abbeys down to modest country churches. Over the ages, medieval altarpieces continuously grew larger and more magnificent. They became symbols of the identity and pride of communities and individuals, for whom they sometimes even became the object of emulation. Altarpieces are at the core of Western art history; one only needs to think about Duccio's Maestà that was erected on the high altar in Siena Cathedral (Italy), Veit Stoß's high altarpiece in St Mary's church in Cracow (Poland) or Gil de Siloe's high altarpiece in the Carthusian monastery of Miraflores, in the vicinity of Burgos (Spain).

Given their eminent status as art works, it is hardly surprising that altarpieces have received the attention of art history since it became an academic discipline. The pioneering study by Joseph Braun, Der christliche Altar in seiner geschichtli- 
chen Entwicklung (1924), remains one of the very few European surveys of the evolution of altarpieces, and a starting point for many later research projects. In southern Europe, most research focused on the splendid art works of the Late Middle Ages, the Renaissance and the Baroque. In central and northern Europe, more attention was paid to the early history of altarpieces. This led to a more thorough understanding of their emergence process, especially since the I980s. It has become clear that the road to the altarpiece was a complex, multi-path process in which different object types were combined, mixed and merged in a variety of innovative ways. In 1999, Verena Fuchß coined the term 'altar ensemble' to express the intrinsic composite character of many early altar decorations. Several recent exhibition projects reached out beyond scholarly circles, including Les premiers retables (XII -début $d u X V^{e}$ siècle). Une mise en scène du sacré, shown in the Louvre in Paris in 2009, and North \& South: Medieval Art from Norway and Catalonia IIO0-I350, held in the Museum Catharijneconvent in Utrecht (the Netherlands) and the Museu Episcopal de Vic (Catalonia, Spain) in 2019-20.

New and wider perspectives have increasingly been adopted in the study of altarpieces, with scholars looking beyond their form and iconography into their purpose as backgrounds to the ritual, creating a stage for the liturgy. This has led to a growing awareness that the meaning and impact of these art works can only be thoroughly understood if they are studied in relationship to the altars to which they belonged, the interior spaces they adorned, with their associated architecture and imagery, and in conjunction with the variety of objects used on and around the altar, including liturgical vessels, books, chandeliers, cloths, vestments, and so on. In addition, altarpieces are more often analysed in their religious context, in relationship to the theology of the Mass, and developments in spirituality and devotion. What has generally remained, however, is the limited geographical scope of most studies, with a focus on specific countries or regions, the oeuvre of individual artists or even individual art works. This means that, with all the progress made in altarpiece research, Braun's European perspective has gradually faded away.

Despite its wide scope, Braun's magnum opus from 1924 fully ignored the tabernacle-altarpiece (also known as tabernacle shrine) as a category of early medieval altar decorations. These can be defined as more or less architecturally shaped enclosures containing one single figure that could be closed off with movable wings. After pioneering articles on this subject by Mojmír Frinta (1967) and Claude Lapaire (1969 and 1972), tabernacle shrines in Sweden were further studied by Peter Tångeberg (1986), while Klaus Krüger researched examples in Italy (1992). The present volume aims to tie into these publications by exploring the tabernacle-altarpiece as a European object type on the road toward the late me- 
dieval altarpiece. Tabernacle-altarpieces were fashionable across Western Europe between the twelfth and the fourteenth centuries, from Finland to Spain and from Iceland to Italy. Despite their often (but not always!) modest size, tabernacle-altarpieces heralded essential aspects of later altarpieces, such as the combination of media (sculpture and painting), the juxtaposition of representational and narrative iconography, and the possibility to conceal and disclose holy figures inside. Moreover, they were by no means superseded by 'fully-fledged' altarpieces, since the phenomenon lived on during the Late Middle Ages.

Due to their age and fragility, most tabernacle-altarpieces from the twelfth to the fourteenth centuries are now lost. Surviving examples are often fragmented, overpainted or reassembled. Almost all have lost their original context, even if they have remained in the churches to which they belonged (Figs I-2). Many others are now kept in museums, where they are often presented as a curiosity or misunderstood as 'portable altars', and mainly neglected by visitors. Most are now in museum storage places, waiting for decades for the rare interested scholar to come and study them. Another factor that has contributed to tabernacle-altarpieces remaining largely unnoticed is the fact that most examples are preserved in the 'periphery' of Europe, in Scandinavia, some parts of Italy and of the Iberian Peninsula. Several rare examples in the heart of Europe, however, clearly confirm their European spread. Today, in France and England, countries that were core innovators in medieval art, practically no examples remain, but iconographic sources prove their existence there too.

The wealth preserved in the periphery of the continent still provides a good impression of the many lost treasures in all the countries that lie in between. As a pan-European phenomenon, surviving tabernacle-altarpieces are outstanding indicators of the religious and cultural unity that characterised the medieval Latin West, particularly between II5O and 1350. Several aspects, such as the decoration of the insides of wings with reliefs, an iconographical focus on the Infancy of Christ, and the rise of architecturally designed baldachins around and after I300, all spread over the continent about the same time. On the other hand, the pluriformity of European tabernacle shrines also stands out, in terms of details in their construction, style and iconographical peculiarities. No two examples are identical, as sculptors, painters, joiners and commissioners constantly searched for tailor-made solutions for specific situations in churches and on altars. This volume aims to explore and celebrate both the unity and variety of medieval tabernacle-altarpieces in Europe by focussing on such aspects as technical and stylistic features, provenance and patronage, as well as the function and role of early tabernacle-altarpieces in liturgical ritual and devotional practice. 
The first two of the essays contained in this volume address general issues. Justin Kroesen and Peter Tångeberg distinguish and define three types of European tabernacle shrines based on the rich Swedish stock. Elisabeth Andersen scrutinises the appearance of closed tabernacle-altarpieces in order to gain a better understanding of how they were used. Stephan Kuhn focuses on Norwegian examples to challenge the assumption that Marian tabernacles generally occupied the northern side altar in medieval churches. Two subsequent essays explore tabernacle-altarpieces in the German-speaking countries of Central Europe. Stephan Kemperdick offers a wide panorama based on tabernacle-altarpieces in these lands, where testimonies are today scarce. Pavla Ralcheva concentrates on examples from the Rhineland, studying their construction, placement and use. Cristiana Pasqualetti discusses tabernacle-altarpieces in Italy, where the variety of types and their long existence in some regions are the most distinctive features. The last four contributions investigate tabernaclealtarpieces in the Iberian kingdoms. Fernando Gutiérrez Baños explores the origins and characteristics of Castilian specimens, while Teresa Laguna Paúl focuses on one of the most outstanding examples, the silver altar of the Virgen de los Reyes in Seville Cathedral. Moving to the Crown of Aragon, Alberto Velasco Gonzàlez provides a survey of tabernacle-altarpieces from these realms, introducing several hitherto neglected examples, and finally, Jordi Camps i Sòria studies the early development of Catalan tabernacle-altarpieces in relation to other altar structures.

This volume is published as part of the research project Retablos-tabernáculo castellanos de la Baja Edad Media: estudio, documentación y difusión (Tabernacle-altarpieces of the Late Middle Ages: Study, Documentation, Spread), reference HAR20I7-82949-P (MINECO/AEI/FEDER, UE), funded by the Spanish Ministry of Economy, Industry and Competitivity with the contribution of the European Regional Development Fund. The contributions originated from an international symposium held in Valladolid on 7-8 June 2019, with support from the University of Valladolid (Instituto Universitario de Historia Simancas, G.I.R. IDINTAR, and Departamento de Historia del Arte), and the Spanish Committee of Art History. During a field trip on 8 June, seven Castilian tabernacle-altarpieces preserved in Burgos and in the Basque Country were visited and examined with the help of the Diocese of Vitoria. However, this publication is fundamentally the result of the generous efforts made by all those colleague-researchers to shed light on one of the most fascinating yet underrepresented chapters of the history of medieval art, as well as by the blind reviewers who contributed to improve the overall volume. 


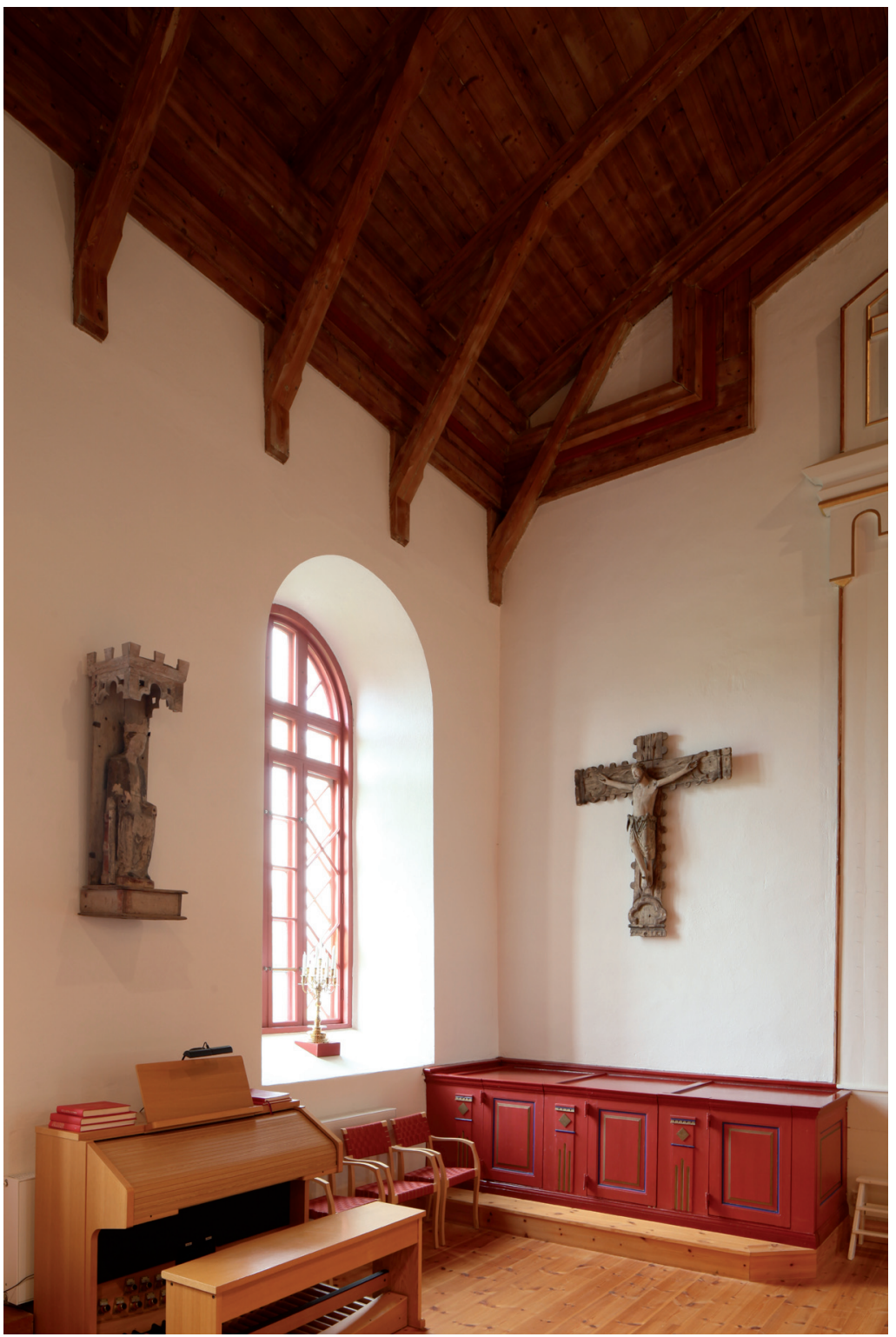

Fig. I. Björketorp (Västergötland, Sweden), a Marian tabernacle (left), wings missing, hanging from the north wall of the nave of the church. Photo: Justin Kroesen. 


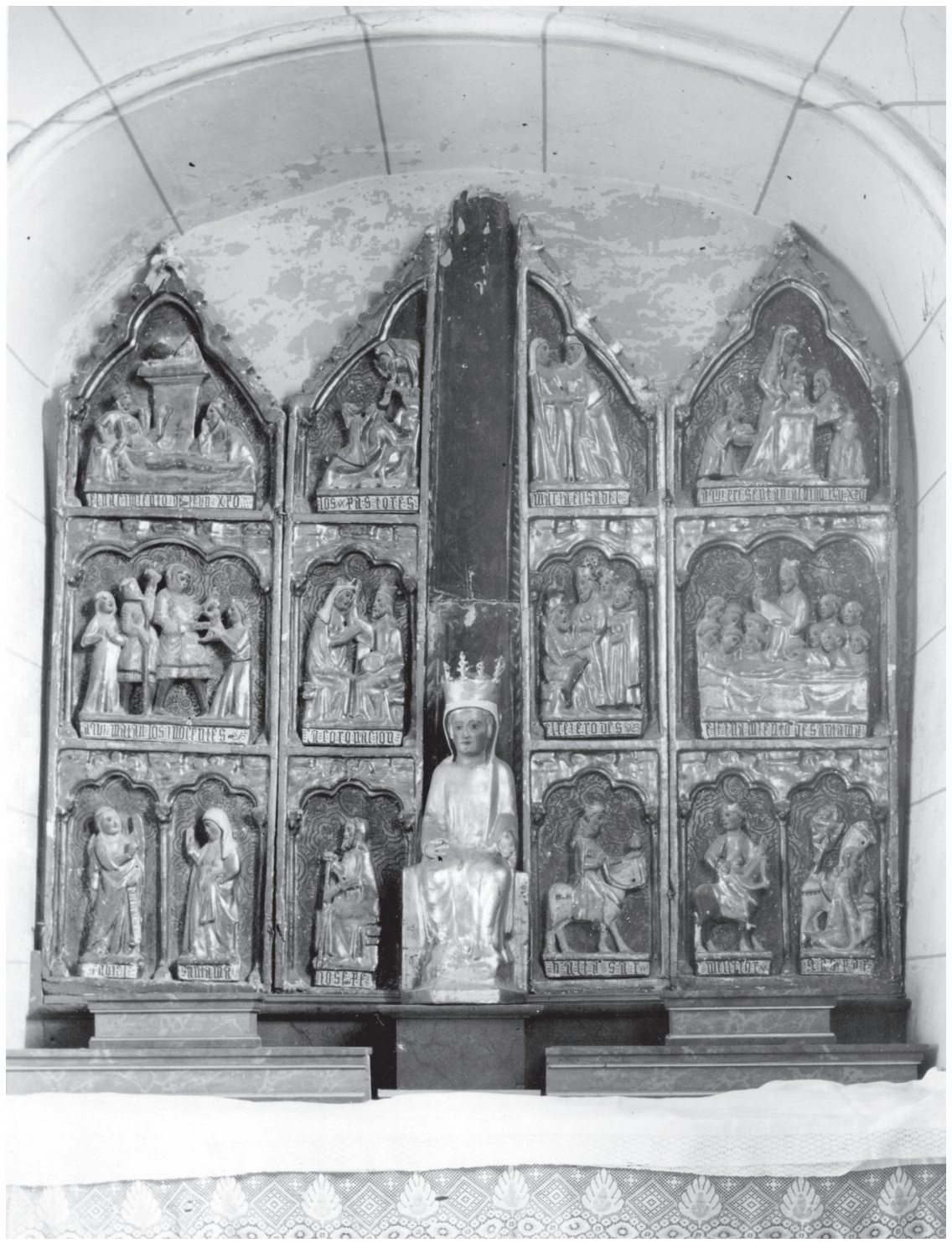

Fig. 2. Yurre/Ihurre (Basque Country, Spain), wings from a Marian tabernacle grouped at a side altar of the church, condition by the mid-twentieth century.

Photo: ATHA-DAF-LÓPEZ DE GUEREÑU-46I5-Foto Gerardo López de Guereñu. The ensemble has been subsequently restored. 